\title{
Detection and disinfection of COVID-19 virus in wastewater
}

\author{
Simranjeet Singh ${ }^{1} \cdot$ Vijay Kumar $^{2} \cdot$ Dhriti Kapoor $^{3} \cdot$ Daljeet Singh Dhanjal $^{4} \cdot$ Deepika Bhatia $^{5} \cdot$ Sadaf Jan $^{3}$. \\ Nasib Singh ${ }^{6} \cdot$ Romina Romero $^{7} \cdot$ Praveen C. Ramamurthy ${ }^{1} \cdot$ Joginder Singh $^{4}$ (I)
}

Received: 13 January 2021 / Accepted: 5 February 2021 / Published online: 22 February 2021

(c) The Author(s), under exclusive licence to Springer Nature Switzerland AG part of Springer Nature 2021

\begin{abstract}
The coronavirus disease 2019, COVID-19, caused by the severe acute respiratory syndrome coronavirus 2, SARS-CoV-2, appears as a major pandemic having adverse impact on public health and economic activities. Since viral replication in human enterocytes results in its faecal shedding, wastewater surveillance is an ideal, non-invasive, cost-effective and an early warning epidemiological approach to detect the genetic material of SARS-CoV-2. Here, we review techniques for the detection of SARS-CoV-2 in municipal wastewater, and disinfectants used to control viral spread. For detection, concentration of ribonucleic acid involves ultrafiltration, ultracentrifugation and polyethylene glycol precipitation. Identification is done by reverse transcriptase amplification, nucleic acid sequence-based amplification, helicase dependent amplification, loop-mediated isothermal amplification, recombinase polymerase amplification, high throughput screening and biosensor assays. Disinfectants include ultraviolet radiations, ozone, chlorine dioxide, hypochlorites and hydrogen peroxide. Wastewater surveillance data indicates viral presence within longer detection window, and provides transmission dynamics earlier than classical methods. This is particularly relevant for pre-symptomatic and asymptomatic COVID-19 cases.
\end{abstract}

Keywords COVID-19 Pandemic $\cdot$ SARS-CoV-2 Wastewater surveillance $\cdot$ Wastewater treatment plants $\cdot$ Disinfection

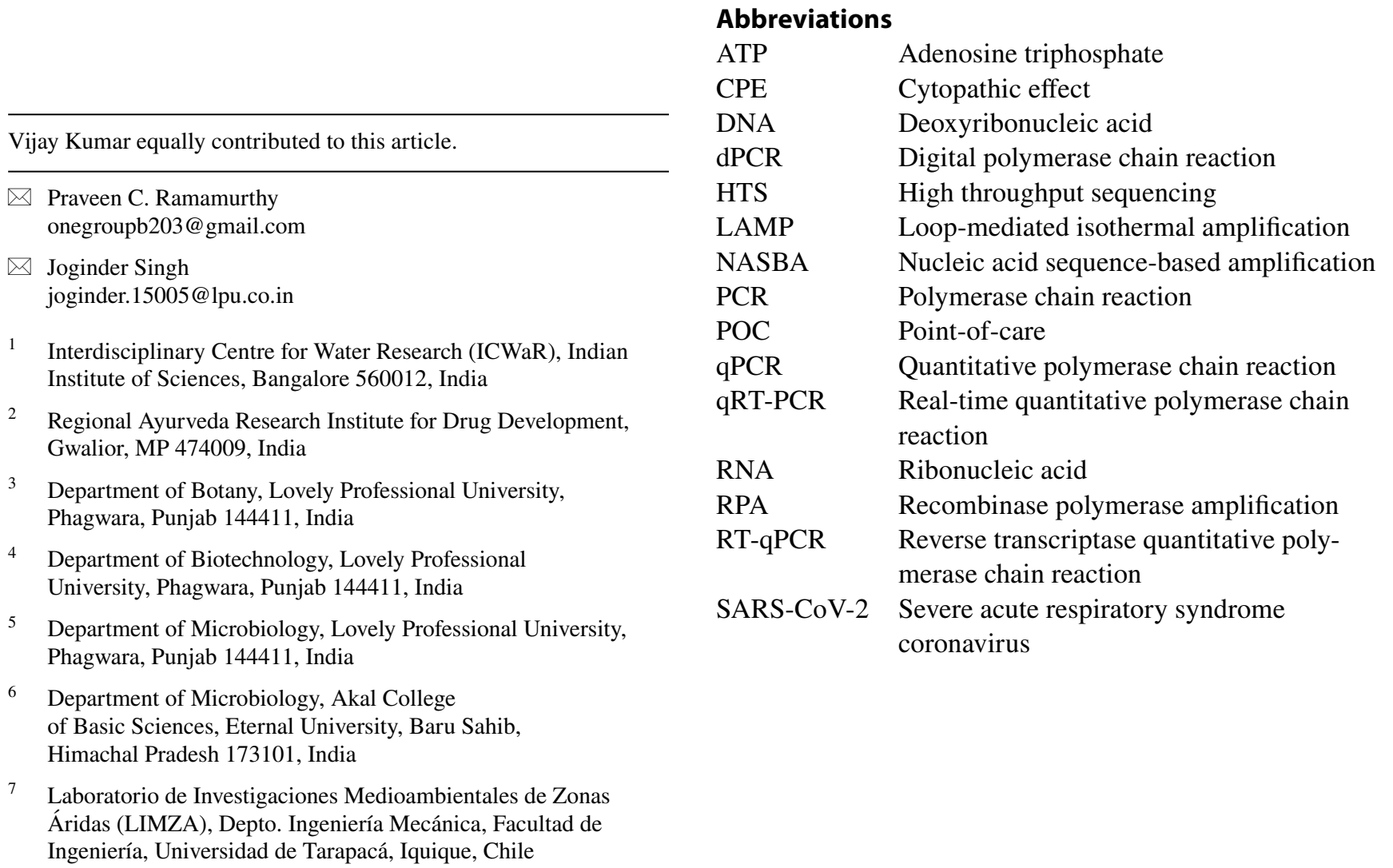




\section{Introduction}

In December 2019, China declared an emergence of an acute form of pneumonia outbreak in Wuhan, Hubei Province, to World Health Organization and its association with novel coronavirus SARS-COV-2 was conclusively established soon thereafter through shotgun metagenomic sequencing of bronchoalveolar lavage samples (Zhu et al. 2020). Since its first reported case in late 2020, the COVID-19 global pandemic has now been confirmed in 222 countries and territories with 101,406,059 confirmed cases and 2,191,898 confirmed deaths as per official data available on World Health Organization website on January 30, 2021 (WHO 2021).

Whilst countries around the world are now progressively starting to reopen and restart after imposing extensive lockdown, the COVID-19 pandemic is still catastrophic and yet to be resolved (Ng et al. 2020; WHO 2021; Chen et al. 2021). World Health Organization along with various international and national health agencies are continuously working synergistically to explore the ways to detect, diagnose, prevent, contain and treat the highly infectious COVID-19 cases at community level. Worldwide, medical researchers and epidemiologists are still finding and exploring new ways to scrutinize, prevent and treat the disease (Dai et al. 2020; He et al. 2021). One of the new ways of analysing the coronavirus is through monitoring the municipal wastewater (Gostin et al. 2020; Lahrich et al. 2020). The viable SARS-CoV-2 and its ribonucleic acid released through human faeces, saliva and sputum eventually find ways in wastewater (Bar Or et al. 2020; Sun and Han 2020). In March 2020, in the Netherlands, scientists found the presence of SARS-COV-2 ribonucleic acid in the sewage samples collected from premises of Schiphol airport, Amsterdam (Medema et al. 2020a). The results came within a week after the first case of COVID-19 was confirmed in the country. These findings opened newer opportunity of utilizing water-based epidemiology (or wastewater surveillance) to determine the spread, persistence and detection of SARS-COV-2 in communities where clinical diagnostic testing is not widely accessible. Water-based epidemiology is an efficient approach to analyse water samples to identify and isolate the microorganisms for public health monitoring (Larsen and Wigginton 2020; Sims and Kasprzyk-Hordern 2020). The water-based approach is not new, as this has been previously used to detect the presence of viruses and bacteria (Kataki et al. 2020).

SARS-COV-2 ribonucleic acid sooner or later ends up in the municipal sewage system, and consequently, wastewater surveillance offers several advantages in comparison with clinical testing of COVID-19 patients as this approach is cost-effective, noninvasive and efficient in providing larger population-wide data (Fig. 1). A study from China revealed the detection of a strain of coronavirus from human faeces samples before the onset of symptoms,

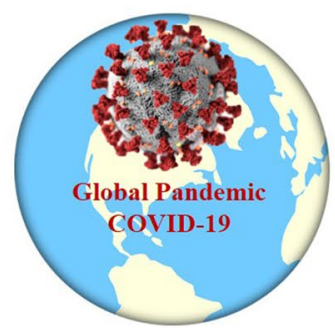

Wastewater Based Epidemiology

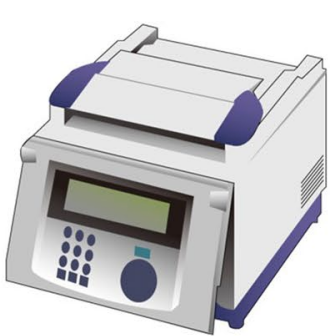

Diagnosis Approaches

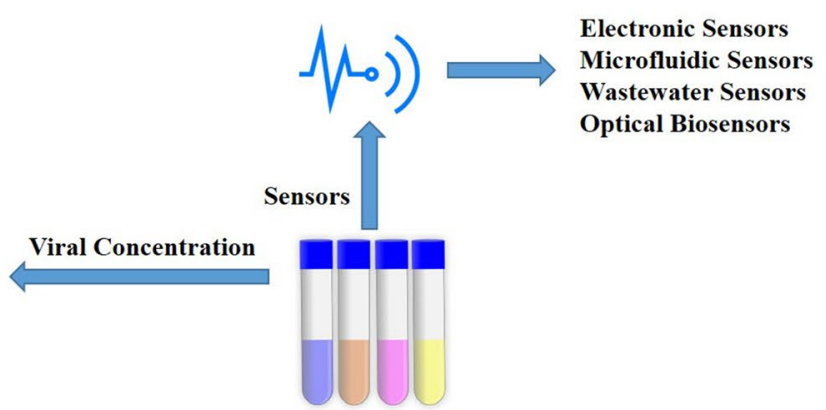

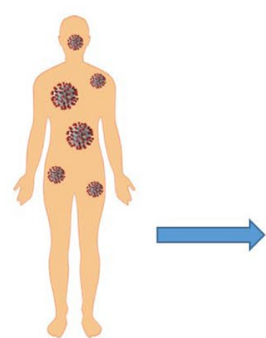

Public Health Emergency
Viral RNA in Feces of Infected Individuals

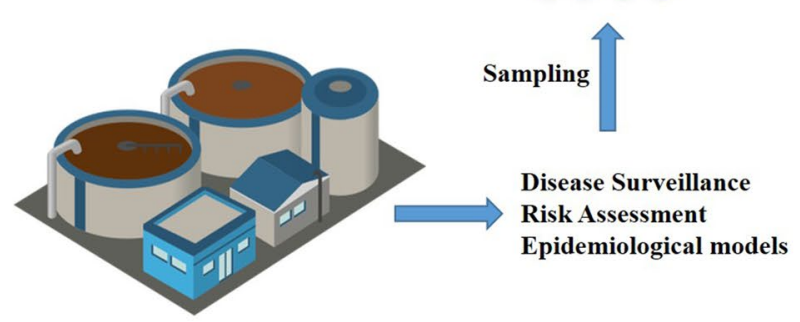

Wastewater Treatment Plant
Fig. 1 Wastewater surveillance epidemiology approach for the monitoring of severe acute respiratory syndrome coronavirus in municipal wastewater treatment plants. Viral ribonucleic acid (RNA) is concentrated followed by detection using polymerase chain reaction based molecular approaches and specifically designed biosensors. This rapid and timely detection of the viral RNA can help to initiate coordinated diagnostic and control strategies against COVID-19 pandemic 
thus indicating the advantage of an early detection (Chan et al. 2020). Further, Yale University researchers showed that monitoring coronavirus strain in sewage water could envisage COVID-19 outbreaks 6-7 days before person testing and 2-3 days before hospital admissions (Peccia et al. 2020). It concludes that water-based approaches are a promising indicator to identify hot spots in the local areas or in a community. Consequently, water-based epidemiology can serve as a cheap, early caution to recognize new pandemic, parameters in current outbreaks and frequency of infections (Rothan and Byrareddy 2020). Numerous research and commercial laboratories have now gained precious knowledge in monitoring water samples for analysis of the virus (Prem et al. 2020).

Environmental scientists are continuously developing effective tools and equipment which can measure and monitor the activities related to the status of health of the entire population over the last 20 years. Nowadays, water-based approaches are beginning to apply for the monitoring of SARS-COV-2 to enumerate the community (Nemudryi et al. 2020). Here, we review technologies available for detection and differentiation of SARS-COV-2 in wastewater samples. Various factors configuring the transmission, survival and infection potential along with their fundamental mechanism is also discussed. The analyses and findings are hence forth represented in this review under various sections and subsections. Current research works on the detection of SARS-COV-2 in wastewater using sensing techniques along with future perspectives are suggested.

\section{Persistence and detection of COVID-19 virus in wastewater}

Contemporary data on SARS-COV-2 and numerous viruses evince that wastewater-based epidemiology is a pragmatic way to assess and palliate viral outbreaks (Randazzo et al. 2020b). Elementary and viable approaches are accessible for the concentration of wastewater samples in order to detect the virus. Conversely, the process controls are recommended as depicted in Fig. 2. The extensively used

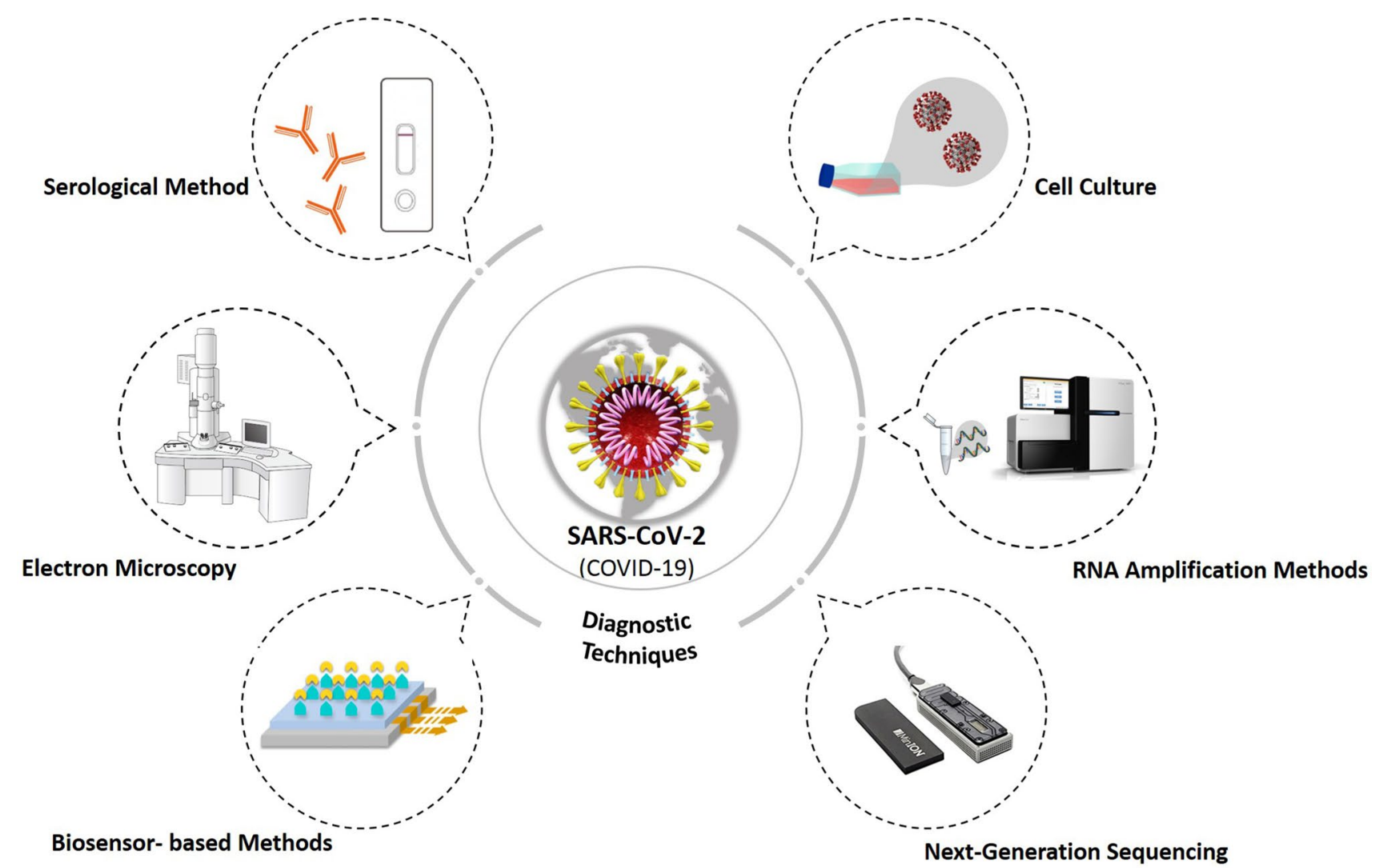

Fig. 2 Techniques available for the reliable and rapid detection of severe acute respiratory syndrome coronavirus or SARS-CoV-2 virus in municipal wastewater. Reverse transcriptase quantitative polymerase chain reaction remains the widely used method of COVID19 virus detection. In addition, immunological assays, viral cultiva-

tion in animal cell cultures, transmission electron microscopy and biosensor-based portable devices are also available. Next-generation high-throughput sequencing is also considered a method of choice for larger sample analyses 
real-time quantitative polymerase chain reaction test allows rapid nucleic acid detection provided the probe and primer selection is accurate and optimized. Regardless of the fact that infectivity state of the specific virus is not appropriate for epidemiological monitoring, the SARS-CoV-2 survival within sewage throughout the treatment process requires a complete analysis to evaluate the health risks. Specific and nonspecific sequencing of sewage viruses probably facilitates tracking the outspread of target variants and detects mutations that may affect viral identification in a clinical framework. To evaluate viral endurance, culturing-based approaches and integrity assays are practised. Amplicon, as well as complete genome sequencing, is exorbitant and laborious, yet having the potential to detect emerging viral strains/species, thus being beneficial for early detection of epidemiological viruses.

\section{Technologies available for COVID-19 virus detection and identification}

\section{Wastewater concentration method}

For sensitive identification of viral strains in municipal wastewater, samples are concentrated prior to quantification. Manifold approaches are prevalently exploited (Bofill-Mas and Rusiñol 2020). Monitoring SARS-CoV-2 entails centrifugation and filtration of wastewater samples in order to obliterate debris and subsequently electronegative membrane filtration (Ahmed et al. 2020), ultrafiltration or polyethylene glycol precipitation (Balboa et al. 2020), aluminium flocculation/ultra-centrifugation (Randazzo et al. 2020b) allowing and facilitating $20 \times-800 \times$ concentration (Wurtzer et al. 2020). Sludge sample is treated by ribonucleic acid extraction explicitly (Peccia et al. 2020) or initiated by virus elution followed by polyethylene glycol precipitation from the matrix (Zhang et al. 2020). Most of the concentration approaches are cost-effective and less arduous howbeit with high sample possessing high turbidity; these techniques emerge as intricate and laborious. The major snag of such approaches is co-concentration of superfluous organic compound, viz. humic substance, impeding the downstream process of virus detection. Withal, concentration efficacy varies among various samples albeit it has been determined in two investigations only intended to identify SARS-CoV-2 within wastewater (Randazzo et al. 2020a) demonstrating 3-50\% of viral retrieval (Table 1). In order to evaluate concentration efficiency, the amount of viral indicator scilicet, gut-associated phages must be collated between processed and unprocessed sample (Medema et al. 2020b).

\section{Viral nucleic acid-based methods}

Several technologies have been reported and implemented for the detection and differentiation of viral nucleic acids in wastewater and sewage. These methods include the following.

\section{Quantitative polymerase chain reaction-based techniques}

Polymerase chain reaction technique aims to target the specific genes of the virus and offers an effective, convenient and reliable solution for wide-scale environmental studies. The conventional approach for monitoring viruses is real-time/quantitative polymerase chain reaction predominantly combined with reverse transcription phase to enumerate ribonucleic acid targets. Polymerase chain reaction performed on a microfluidic platform reduces the time and expenditure of the assay. Microfluidic-based quantitative polymerase chain reaction detects manifold viruses from water samples. Although it utilizes low amount sample and exiguous amplification reaction mixes with increased detection efficiency, as exemplification 150 copies/ $\mu$ l (Woelfel et al. 2020), yet it not considered to be standard for most environmental samples.

The prominent technique for quantification of the virus is digital reverse transcriptase polymerase chain reaction where reaction mixes are disseminated within thousand to million separate wells placed on-chip/ $\mathrm{H}_{2} \mathrm{O}-$ oil droplets and further quantification is computed based on + or - signals. Digital reverse transcriptase polymerase chain reaction is a rapid and extremely sensitive technique facilitating the strain-level identification of nearly one to ten genome copies in approximately 1 to $4 \mathrm{~h}$. This method is more advantageous over quantitative polymerase chain reaction due to executing absolute quantification, without the requirement of any standards. Comparative analysis manifests that digital polymerase chain reaction is highly sensitive and is seldom affected by any sort of inhibitors rather than quantitative polymerase chain reaction techniques (Jahne et al. 2020). Howbeit, digital quantitative polymerase chain reaction features a narrower range of quantification compared to its quantitative counterpart (Qiu et al. 2020); therefore, sample bearing high viral concentration, viz. wastewater samples, must be diluted prior conducting digital reverse transcriptase polymerase chain reaction. Probe-based quantitative polymerase chain reaction using TaqMan, a target-specific probe, is multiplexed, allowing the parallel identification of two to four targets within single well (Ahmed et al. 2020). This might prove propitious for concurrent quantification of the animal as well as a human for tracking the source. Commercially available multiplex quantitative polymerase chain reaction testing is used to detect viral pathogens excretes (Hirvonen 2019). A duplex assay in which digital reverse transcriptase 
Table 1 Methodologies employed for the detection of severe acute respiratory syndrome coronavirus nucleic acids in municipal wastewater

\begin{tabular}{|c|c|c|c|c|}
\hline Region/country & Wastewater sample & $\begin{array}{l}\text { Sample volume } \\
\text { analysed }(\mathrm{ml})\end{array}$ & $\begin{array}{l}\text { Technique(s) used for wastewa- } \\
\text { ter concentration }\end{array}$ & References \\
\hline Wuhan, China & $\begin{array}{l}\text { Untreated and treated waste- } \\
\text { water }\end{array}$ & na & $\begin{array}{l}\text { Centrifuged supernatant sub- } \\
\text { jected to polyethylene glycol } \\
\text { precipitation }\end{array}$ & Zhang et al. (2020) \\
\hline Murcia, Spain & $\begin{array}{l}\text { Untreated and treated waste- } \\
\text { water }\end{array}$ & 200 & $\begin{array}{l}\text { Aluminium flocculation (Beef } \\
\text { extract precipitation) }\end{array}$ & Randazzo et al. (2020a) \\
\hline Milan and Rome, Italy & Untreated wastewater & 250 & $\begin{array}{l}\text { Centrifuged supernatant sub- } \\
\text { jected to polyethylene glycol } \\
\text { or dextran precipitation }\end{array}$ & La Rosa et al. (2020) \\
\hline $\begin{array}{l}\text { Southeast Queensland, Aus- } \\
\text { tralia }\end{array}$ & Untreated wastewater & $100-200$ & $\begin{array}{l}\text { Electronegative filtration } \\
\quad(\mathrm{pH} \sim 4)\end{array}$ & Ahmed et al. (2020) \\
\hline Israel & Untreated wastewater & $250-1000$ & $\begin{array}{l}\text { Centrifuged supernatant sub- } \\
\text { jected to alum/polyethylene } \\
\text { glycol precipitation, Amicon } \\
\text { ultrafiltration }\end{array}$ & Bar Or et al. (2020) \\
\hline Netherlands & Untreated wastewater & $36-150$ & $\begin{array}{l}\text { Centrifuged supernatant sub- } \\
\text { jected to Centricon ultrafil- } \\
\text { tration }\end{array}$ & Medema et al. (2020b) \\
\hline Paris, France & $\begin{array}{l}\text { Untreated and treated waste- } \\
\text { water }\end{array}$ & 11 & Ultracentrifugation & Wurtzer et al. (2020) \\
\hline Valencia, Spain & $\begin{array}{l}\text { Untreated and treated waste- } \\
\text { water }\end{array}$ & 200 & $\begin{array}{l}\text { Aluminium flocculation (beef } \\
\text { extract precipitation) }\end{array}$ & Randazzo et al. (2020b) \\
\hline Istanbul, Turkey & Untreated wastewater & 250 & $\begin{array}{l}\text { Centrifuged supernatant sub- } \\
\text { jected to Amicon/polyethyl- } \\
\text { ene glycol precipitation }\end{array}$ & $\begin{array}{l}\text { Alpaslan Kocamemi et al. } \\
\text { (2020) }\end{array}$ \\
\hline Connecticut, USA & Primary sludge & 2.5 & RNA extraction & Peccia et al. (2020) \\
\hline Ourense, Spain & $\begin{array}{l}\text { Untreated, treated wastewater } \\
\text { and sludge }\end{array}$ & 250 & $\begin{array}{l}\text { Centrifuged supernatant sub- } \\
\text { jected to Amicon ultrafiltra- } \\
\text { tion }\end{array}$ & Balboa et al. (2020) \\
\hline Massachusetts, USA & Untreated wastewater & na & $\begin{array}{l}\text { Polyethylene glycol precipita- } \\
\text { tion }\end{array}$ & Wu et al. (2020) \\
\hline Montana, USA & Untreated wastewater & 500 & Corning spin-X ultrafiltration & Nemudryi et al. (2020) \\
\hline Ahmedabad, Gujarat, India & $\begin{array}{l}\text { Untreated and treated waste- } \\
\text { water }\end{array}$ & 50 & $\begin{array}{l}\text { Centrifuged supernatant sub- } \\
\text { jected to polyethylene glycol } \\
\text { precipitation }\end{array}$ & Kumar et al. (2020) \\
\hline
\end{tabular}

$n a$ Not available; $R N A$ ribonucleic acid

polymerase chain reaction is multiplexed, allowing detection of the virus in clinical trials (Yurick et al. 2019). The disadvantages associated with digital reverse transcriptase polymerase chain reaction method include exorbitant cost, long turnaround time and unavailability for remote settings which in turn limit the extensive use of the aforementioned techniques in environmental investigations and routine monitoring.

\section{Isothermal amplification}

Isothermal amplification techniques including helicasedependent amplification, loop-mediated isothermal amplification, recombinase polymerase amplification and nucleic acid sequence-based amplification possess the ability to determine the low concentration of desired deoxyribonucleic acid and/or ribonucleic acid within $15-60 \mathrm{~min}$ at $37{ }^{\circ} \mathrm{C}$ to $65^{\circ} \mathrm{C}$. These approaches can detect pathogens within environmental samples (Zhang et al. 2020). In loop-mediated isothermal amplification, three sets of primers are used, thus allowing the formation of loop sequence and addition in primer binding sites, through each of the amplification. Thus, loop-mediated isothermal amplification is considered vastly specific and generates significantly more amplicons compared to polymerase chain reaction with less time period and excluding thermal cycler. This technique can further be multiplexed via implementing reverse transcriptase step for detecting ribonucleic acid targets (Zhang et al. 2018). Moreover, loop-mediated isothermal amplification has minimum sensitivity towards inhibitors rather than polymerase chain reaction (Huang et al. 2018). Considering its inherent convenience, reliability and preciseness, 
the loop-mediated isothermal amplification approach can be performed in the assessment of virus in wastewater and sewage collected in municipal wastewater treatment plants. Nucleic acid sequence-based amplification and recombinase polymerase amplification operate with a combination of enzymes in order to promptly amplify multiple nucleic acid targets. Unlike other amplification techniques, nucleic acid sequence-based amplification directly amplifies from the target sequence, thereby not demanding reverse transcription step. Conversely, the complexity of recombinase polymerase amplification and nucleic acid sequence-based amplification render them susceptible toslowing down compared to other techniques (Rames and Macdonald 2019). It has been proposed that due to the ability of nucleic acid sequence-based amplification, it can be implemented for environmental viral load detection (Hønsvall and Robertson 2017). However, the challenges in producing reliable results and the high cost of nucleic acid sequence-based amplification limit its wider applications as a regular method for detection of virus in environment samples (Walker et al. 2017).

\section{High-throughput sequencing}

High-throughput sequencing can be utilized to identify nucleic acids of several viral pathogens from freshwater, wastewater and sewage samples. Therefore, high-throughput sequencing has the potential to detect emergent viruses and related pathogens in environment water bodies (Adriaenssens et al. 2018). To recover the whole genome of noncultured viruses from metagenomics data generates genotype-level detection and assists the quantitative polymerase chain reaction assays for better scale surveying (Huang et al. 2019). High-throughput sequencing for target amplicon sequencing produces finer resolution geographical distribution (Young et al. 2020) as well as diversity (Hata et al. 2018). However, quantitative polymerase chain reaction and high-throughput sequencing at times yield conflicting indication on the occurrence of target viruses whilst data processing provides chimeric sequences and artefacts. Long-read sequencing facilitates to overcome such limitations, despite that it yields nearly 15\% error rate (Rang et al. 2018). However, some disadvantages of high-throughput sequencing approach, i.e. high cost, complex setup, need for expertise and voluminous computational analysis, limit its application in routine analysis of wastewater.

\section{Assessment of viral infectivity}

The nucleic acid detection systems do not provide any reliable information about the virulence of the pathogens. Culturing human-associated viruses entails particular equipment, for example, $\mathrm{CO}_{2}$ incubator and inverted microscope. It also requires finely maintained cell lines, yet not often exploited in regular viral monitoring (Pang et al. 2019). In contrast, the existing approaches, for instance, the cytopathic effect for examining cell lysis induced by the morbific virus, take weeks. However, the aforementioned approach has the potential to determine the viral infectivity, which is crucial for wastewater treatment. Researchers are endeavouring to simplify and promote viral culturing methods (Farkas et al. 2020a). Integrated cell culture along with reverse transcriptase quantitative polymerase chain reaction reduces the time needed for culturing. It provides results of virus detection within 1-4 days, where the concentration of nucleic acid elevates because of viral propagation which can further be accurately examined via reverse transcriptase quantitative polymerase chain reaction. Lately, such available techniques are being implemented for identifying enteric viruses in environmental water bodies (Sedji et al. 2018). Further, time periods of the aforementioned assays can be curtailed up to hours via virus identification done during the initial stage of cell attachment (Zou et al. 2020). Reverse transcriptase quantitative polymerase chain reaction has an advantage where only a single cell line is used for procreation of various viral strains, allowing the estimation of diverse targets within water sample different (Pang et al. 2019). In viral culturing, the main focus is expressed on the proliferation of human norovirus. From the time 2016, three techniques have been established, exploiting zebrafish embryos (Van Dycke et al. 2019), human B cells (Jones et al. 1939), intestinal epithelial cells (Sato et al. 2019) and human stem cellextracted enteroids (Ettayebi et al. 2016). The aftermath of these approaches exhibits augments in genome copies in 2 to 4 days. But, implementing these methods for environmental sample analysis has not been conducted.

\section{Assessment of viral structural integrity}

By virtue of several drawbacks encountered in ribonucleic acid and deoxyribonucleic acid and culturing-based virus detecting assays, the uncomplicated and cost-effective assays have been established for estimating the integrity of virus in terms of morbific particle intact with it.

\section{Obliteration of free viral nucleic acids}

Elimination of free ribonucleic acid and deoxyribonucleic acid is done via enzymatic treatment DNase/RNase, by which nonencapsidated viral ribonucleic acid and deoxyribonucleic acid deteriorate, prior polymerase chain reaction assay for quantification. Enzymatic assays manifest moderate elimination of free ribonucleic acid and deoxyribonucleic acid (Leblanc et al. 2019). Oftenly, DNase/RNase enzymatic assay is coupled with proteinase $\mathrm{K}$ processing that deteriorates the capsid proteins, allowing nucleases to approach ribonucleic acid and deoxyribonucleic acid 
from noninfective viral particles. Howbeit, proteinase $\mathrm{K}$ action causes impairment to morbific viral particles; also, ergo must be processed with caution (Langlet et al. 2018). Another discrete method to annihilate free ribonucleic acid and deoxyribonucleic acid is viability treatment, where intercalating dyes are used. These dyes are capable of penetrating viral capsids and on the exposure of lights samples covalently bind to ribonucleic acid and deoxyribonucleic acid molecules, thereby precluding polymerase amplification (Leifels et al. 2019). The most extensively used dyes are ethidium monoazide and propidium monoazide. In other viability treatment, the binding substances used are cis-dichlorodiammineplatinum and platinum chloride and do not require light exposure to bind with ribonucleic acid and deoxyribonucleic acid. The aforementioned substances happened to be tested chlorinated/inactivated viral samples (Canh et al. 2019). The outcomes of these treatments evince that most ribonucleic acid and deoxyribonucleic acid molecules are eliminated, barring variations among various samples and viral strains (Monteiro and Santos 2018). Propidium monoazide treatment can be advanced via adding surfactants (Randazzo et al. 2018) or can be coupled with ethidium monoazide (Canh et al. 2019). These assays are propitious as not being strain-specific, therefore allowing multiple target analysis in a single sample.

\section{Capsid functional integrity assay}

In this test method, the affinity binding occurs between viral capsid and proteins. Due to high variation exhibited by capsid protein, one assay is applicable for few species/strains only but must belong to the same family. The latest investigations emphasize capsid integrity concerning noroviruses, specifically genotype II, estimated via histo-blood group antigens such as porcine gastric mucin. For these proteins, immobilization is done on magnetic beads/plate wells (Tian et al. 2018). Binding of virus particles with proteins after sample addition followed by washing steps assists in the elimination of viral ribonucleic acid as well as inhibitors that may hinder polymerase chain reaction-based identification. This method is simpler rapid and convenient; it can be practised in nearly all laboratories. Yet it seems ineffective for norovirus genotype I compared to genotype II (Farkas et al. 2020b).

\section{Biosensors}

Biosensors convert biological responses into quantifiable signals subsequent to the association with a specific target (Shen et al. 2019). Biosensors based on aptamer referred as aptasensors contain single-stranded ribonucleic acid or deoxyribonucleic acid oligonucleotides, having the potential to attach target deoxyribonucleic acid/proteins, possessing high affinity and specificity moreover producing quantifiable signals upon binding. Aptasensors based on colorimetric, electrochemical, fluorescence and surface plasmon resonance detection platforms are established for norovirus identification (Weerathunge et al. 2019) and may prove favourable for viral identification in aquatic samples. Aptamers usually can outlast environmental inhibitors, allowing more recoveries and higher detection within minutes (Schilling et al. 2018). Few aptamers have the ability for multiple detections in various norovirus strains (Shen et al. 2019). As the need for rapid diagnosis of COVID-19 cases is escalating, point-of-care or POC biosensors gained tremendous environmental (Kalyani et al. 2020) and diagnostic importance (Choi 2020). Both chip-based and paper-based biosensors are useful for the detection of SARS-CoV-2 owing to their low cost, high sensitivity, portability, ease of handling, amenability miniaturization and multiplexing, and quick result outcomes (Choi 2020; Parihar et al. 2020). In the present demanding situation for COVID-19, research focus is oriented towards development of optical, electrochemical, microfluidics and paper-based biosensors for reliable and sensitive diagnosis of SARS-CoV-2 infection, especially in emerging COVID-19 hot spots (Parihar et al. 2020).

\section{Electronic biosensors}

Field-effect transistors, amperometric and 3 electrodepotentiometric systems are fundamental electronic biosensors extensively applicable in the identification of biological molecules and causative agents. The chief advantage of aforesaid biosensors is compactness, cost-effective and abundant manufacturing. Field-effect transistors are effortlessly designed in complementary metal oxide semiconductor setups (Syu et al. 2018), albeit manifold portable electrochemical biosensors are available for sale in markets (Stoian et al. 2020). Earlier numerous electrochemical biosensors were established for viral pandemics. Researchers designed single microfluidic electrochemical biosensor for identification of H7N9, H1V1 and H5N1, amalgamated with zinc oxide nanorods (Han et al. 2016; Jyoti and Tomar 2017), and amplification approaches were utilized for sensitive diagnosis of H1N1 via electrochemical biosensors (Li et al. 2012), electrochemical identification of Middle-East respiratory syndrome virus employing carbon electrodes (Layqah and Eissa 2019), screening of severe acute respiratory syndrome virus (Ishikawa et al. 2009) and various other proceedings exploiting disposable screen-printed electrodes as well as paper-based substrates to detect diverse viruses (Malecka et al. 2016). Few investigations foster to develop procedures for early identification of COVID-19 outbreak. Researchers notified a field-effect transistor biosensor for identifying SARS-CoV-2 in clinical samples (Seo et al. 2020). These sensors are made of graphene sheets coated on transistors, 
containing an antibody specific to SARS-CoV-2 spike protein. These biosensors have the potential to detect SARS$\mathrm{CoV}-2$ spike protein at $11 \mathrm{fg} / \mathrm{ml}$ concentration in buffer solvents formulated in the laboratory as well as $100 \mathrm{fg} / \mathrm{ml}$ of biological samples. This is an epitome of how biosensors are used for detection of viral strains at minimal concentration and devoid of sample pretreatment/labelling.

\section{Microfluidic biosensor}

Microfluidics method is meticulous and manipulates microscale fluids (Reboud et al. 2019). The elementary operating units, viz. detection, extraction, preparation and reaction, concerning many processes are amalgamated on the microchip. These microfluid channels, detectors, pumps, sensors and valves are fabricated on polymer, silicon or metal via micromachining approach. Previously, microfluidics has been implemented using numerous analytical technologies such as mass spectrometry, electrochemical analysis, chemiluminescence and fluorescence analysis (Zhang et al. 2019). Microfluidic setup is categorized into electrokinetic, capillary, centrifugal, pressure-driven and acoustic systems based on liquid propulsion standards (Nasseri et al. 2018). Over the years, microfluidic biosensors were employed to detect infectious diseases within the medical sector. For instance, acoustic wave biosensors bearing horizontal surface were acknowledged for multiple identifications of anti-gp 41 and anti-p 24 antibodies associated with human immunodeficiency virus (Gray et al. 2018). Microfluidic biosensors have the potential to discern human immunodeficiency virus biomarkers in 5 min using a little amount of sample $(6 \mu \mathrm{l}$ of plasma), thereby being a cost-effective and rapid diagnostic tool. Another microfluidic biosensor based on silicon nanowire was established to identify reverse transcriptase quantitative polymerase chain reaction derivatives associated with Dengue serotype 2 (Zhang et al. 2010). During COVID-19 pandemic, prompt diagnostic tools/approaches are of tremendous significance for timely detection of SARS-CoV-2, leading to adequate treatment. Microfluidic biosensors have many advantages over rudimentary methods, viz. a culture-based and molecular approach. The aforesaid method is economical, rapid, precise, portable, highly reproducible, consumption of less sample/reagent and highthroughput processing (Nasseri et al. 2018).

\section{Wastewater biosensors}

Wastewater-based epidemiology is an analytical method employed to divulge discernments about public health via examining contents of desired regions sewage. Wastewaterbased epidemiology is a significant tool to trace the dissemination of viruses in the public sector, thereby endowing with opportunities to assess its prevalence, diversity and distribution (Ahmed et al. 2020). The technique entails chemical analyses of samples collected from sewage plants. This technique enables us to get insights, to obtain effective information about human health, pathogens, diseases, illicit and licit drugs (Mao et al. 2020). Human viruses including salivirus, enteroviruses, rotaviruses, astroviruses and noroviruses have been identified in water and wastewater via wastewater-based epidemiology, suggesting their presence to be an efficacious approach for early detection of the viral outbreak through consistent monitoring of the diversity as well as the concentration of pathogens in wastewater (O'Bannon 2020). Scientists are trying to explore wastewater-based epidemiology to precisely monitor the outbreak of COVID-19 from sewage. SARS-CoV-2 has been detected in faecal samples of positive cases across various countries such as China (Chen et al. 2020), Germany (Woelfel et al. 2020), Korea (Kim et al. 2019), USA (Holshue et al. 2020) and Singapore (Young et al. 2020), thereby increasing viral load within wastewater of infected area. Consequently, wastewater-based epidemiology can be employed as an early detecting tool for the prevalence of COVID-19 onset, whilst providing an accurate estimation of the spread of pandemic (Corman et al. 2020). Researchers are carrying out a study to implement wastewater-based epidemiology technique to deal with an ongoing pandemic (Verma and Rani 2020). Biomedical and chemistry are being integrated in order to fabricate wastewater-based epidemiology as rapid and effective means to monitor the spread of SARS-CoV-2 (Mao et al. 2020; Sharma et al. 2020).

\section{Optical biosensors}

Numerous optical biosensors predominantly based on the concept of plasmonics (Qiu et al. 2020) basically where the transduction standards exploit optical constituents including, lasers (Ma et al. 2019), waveguides (Rodriguez et al. 2019), photonic crystals (Rodriguez et al. 2019) and fibre optics (Socorro-Leránoz et al. 2019) are categorized as optical sensors. Optical biosensors, for example, surface plasmon sensors, comprising localized surface plasmon resonance are accessible for commercial sale since the 1990s. It is used to identify viral strains, mostly the one that is associated with H1N1 (Kamikawa et al. 2012), influenza (Takemura et al. 2017), severe acute respiratory syndrome (Seo et al. 2020) and Middle East respiratory syndrome (Layqah and Eissa 2019). Various plasmonic approaches possessing sophisticated surface chemistry render high sensitivity, rapid response for detection of pathogen and selectivity. The challenge in operating this technique remains enormous size and expenditure of instrumentation required for fabricating plasmonic systems. Yet these sensors have accuracy in detecting viruses during a pandemic. Researchers established a biosensor for precise detection and analyses of SARS-CoV-2 
Fig. 3 Disinfection methods for efficient inactivation of severe acute respiratory syndrome coronavirus or SARS-CoV-2 virus in municipal wastewater. Chemical disinfectants represented by nonhazardous chlorine-containing compounds (hypochlorites or bleach and chlorine oxide) and hydrogen peroxide are useful for disinfection of COVID-19 virus in wastewater treatment plants. Other disinfection processes based on ultraviolet irradiation and ozonization are equally effective and amenable to widespread applications

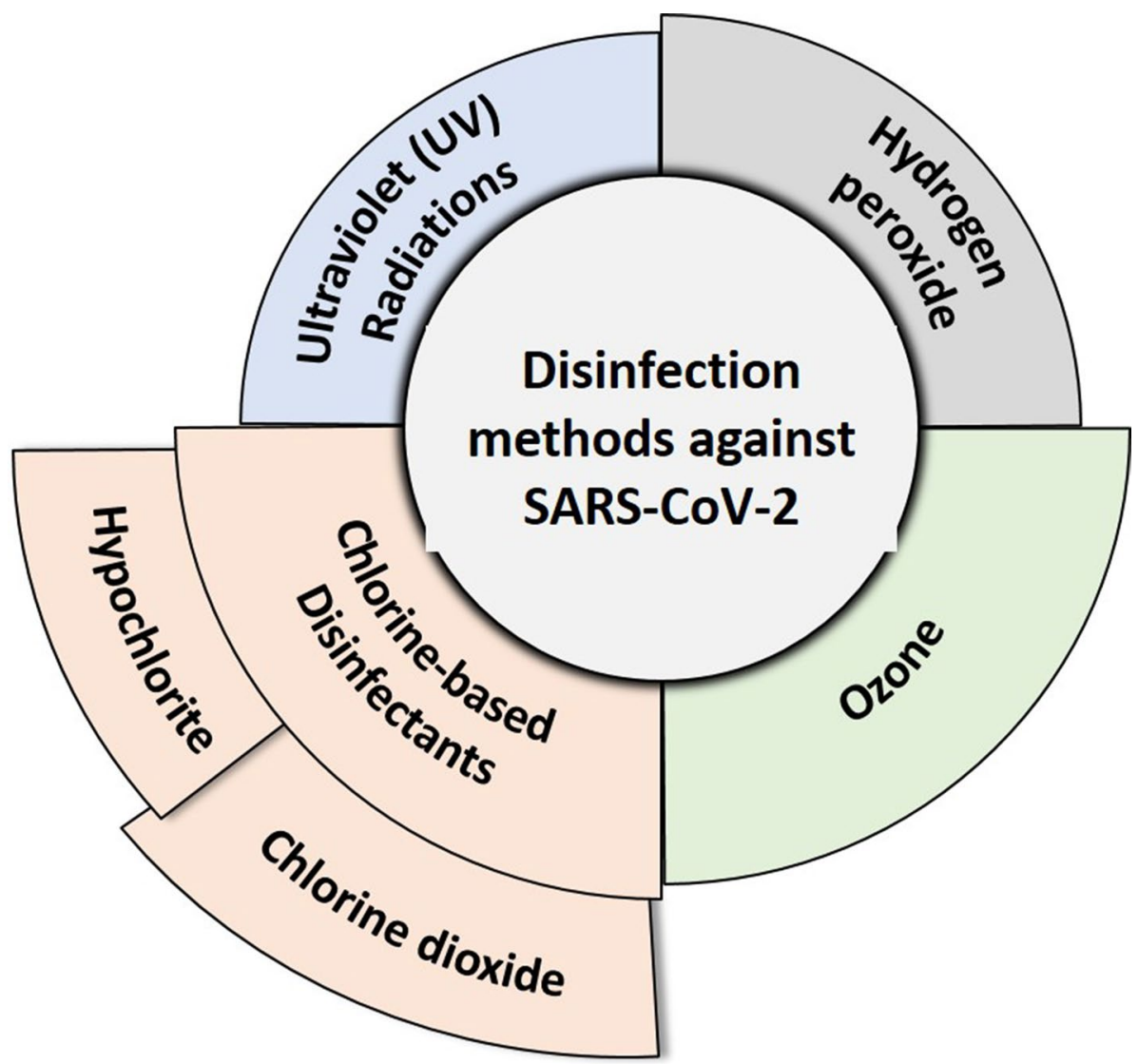

cases employing a plasmonic photothermal effect, and localized surface plasmon resonance is assembled as transduction standards (Qiu et al. 2020). Primarily, the deoxyribonucleic acid receptors are utilized to identify desired sequences obtained from SARS-CoV-2 via nucleic acid hybridization. Using nanoparticles and illumination in localized surface plasmon resonance sensing a prominent thermoplasmonic frequency is generated. Researchers claim to improve the in situ hybridization temperature by implementing thermoplasmonic heat that can facilitate the meticulous perception of similar gene sequences. Optical biosensors can perform remarkably in high-resolution imaging of viral strains during pandemic conditions.

\section{Disinfection methods against SARS-CoV-2 in wastewater}

Disinfection of wastewater having COVID-19 viruses is as important as disinfection of healthcare facilities, medical instrumentation public transport and other public use amenities for containing the spread of COVID-19 (Crini and Lichtfouse 2019; Li et al. 2020; Wang et al. 2020; Choi et al. 2021). The various methods applicable for wasterwater treatment specific to COVID-19 virus are mentioned in Fig. 3 and described below:

\section{Ultraviolet radiations}

Ultraviolet radiations having wavelengths ranging from 200 to $400 \mathrm{~nm}$ have been extensively employed to disinfect drinking water as early as in 1910 (Leifels et al. 2019). Ultraviolet radiations can be segregated into four wave bands on the basis of distinct wavelengths, comprising ultraviolet A (315 to $400 \mathrm{~nm})$, ultraviolet B (280 to $315 \mathrm{~nm})$, ultraviolet $\mathrm{C}$ (200 to $280 \mathrm{~nm}$ ) and vacuum ultraviolet (100 to $200 \mathrm{~nm}$ ). Therein, vacuum ultraviolet cannot be implemented for disinfection, as it gets absorbed by wastewaters. Wavelength ranging between 200 and $300 \mathrm{~nm}$ deteriorates the genetic materials of microorganisms, including bacteria and viruses, thereby preventing protein synthesis. Ultraviolet $\mathrm{B}$ and Ultraviolet $\mathrm{C}$ can be utilized for disinfection of wastewaters due to excellent bactericidal effect. It is usually considered that the wavelength of $253.7 \mathrm{~nm}$ is optimum for ultraviolet disinfection. In contrast to chlorine disinfection, the ultraviolet disinfection is meant to be significantly more economical. Howbeit, intermittently ultraviolet $\mathrm{C}$ is regarded unsatisfactory due to inadequate depth of penetration and includes some health risks as well. The possibility 
for eradicating micropollutants from wastewater is ultraviolet light or hydrogen peroxide as an advanced oxidation process (Shu et al. 2016). Lately, the Gold Bar Wastewater Treatment Plant implemented this approach in Edmonton, Canada, to remediate secondary sewage (Cuerda-Correa et al. 2019). Thereafter, this method has gained enough attention, due to the presence of hydroxyl radical, which is extremely reactive to impair intractable compounds present in wastewater (Chollom et al. 2020). Advanced oxidation processes including ultrasonic process, Fenton processes photo-catalysis, ozone combined with ultraviolet/catalysts/ hydrogen peroxide or both ultraviolet and hydrogen peroxide have been efficiently used to treat wastewater.

\section{Chlorine-based disinfectants}

Disinfection approaches liberating free available chlorine such as hypochlorous acid and hypochlorite ion persist as the most effective way to address viral contamination (Lee et al. 2018). Most eminent sources of free available chlorine are sodium hypochlorite, calcium hypochlorite chlorine dioxide, elemental chlorine, chloroisocyanurates and chloramines. Hypochlorite being a powerful oxidizing agent is potent for oxidizing organic pollutants; however, undissociated hypochlorous acid is predominantly the microbicidal agent. Inactivation of chlorine is caused by various factors including oxidation of sulfhydryl enzyme and amino acids, reduced nutrient uptake, ring chlorination of amino acids, reduced oxygen uptake, loss of intracellular contents, inhibited protein synthesis, reduced oxidation of respiratory products, downregulation of deoxyribonucleic acid synthesis, decreased adenosine triphosphate production and deoxyribonucleic acid fragmentation (Leifels et al. 2019). Research has affirmed the efficacy of chlorine upon viruses; howbeit, viruses exhibit more tolerance towards chlorine disinfectants relatively than bacteria, and it might be due to the virus attribute, which is lack of metabolic enzyme system. Conventionally, $30-50 \mathrm{mg} / \mathrm{l}$ and $15-25 \mathrm{mg} / \mathrm{l}$ of chlorine are supplemented to wastewater subsequent to primary and secondary treatment of wastewater (Zhang et al. 2020). Earlier findings emphasized that free chlorine residue ranging between 0.2 and $0.5 \mathrm{mg} / \mathrm{l}$ for municipal wastewater is adequate to disinfect severe acute respiratory syndrome virus promptly (Lu et al. 2013). $\mathrm{pH}$ is a decisive factor in inactivation of viruses, at low $\mathrm{pH}$, the inactivation rate is more compared to high $\mathrm{pH}$. The $\mathrm{pH}$ is a modulating factor that determines the dissociation of hypochlorous acid to lesser microbicidal form hypochlorite ion (Zhang et al. 2020). The primary concern in efficacious chlorination is $\mathrm{pH}$, the demand for chlorine and the presence of ammonia.

\section{Hypochlorites}

Aqueous solutions of $5.25 \%$ to $6.15 \%$ sodium hypochlorite are most commonly used chlorine disinfectant. Hypochlorite is considered to be a more effective virus disinfectant compared to chlorine dioxide against SARS-CoV (Zhang et al. 2020). It was observed that the chlorine solution delivered through hypochlorite in the concentration of $>10 \mathrm{mg} / \mathrm{l}$ could entirely inactivate the SARS-CoV after a contact time of $30 \mathrm{~min}$. Studies reported the absolute inactivation of SARS-CoV when incubated at $0.05 \%$ hypochlorite solution in less than $1 \mathrm{~min}$ of time. However, it is regarded as a broad-spectrum microbicidal disinfectant, whilst at high $\mathrm{pH}$ hypochlorite ion acts as a slower virus disinfectant. It can be used on a small scale as a virus disinfectant due to its moderately low residual toxicity, robust activity, easy handling, cost-effective and stable performance.

\section{Chlorine dioxide}

Chlorine dioxide disinfectant is more convenient than chlorine. It is exemplary for virus inactivation and is considered an alternative for chlorine (Lee et al. 2018). Chlorine dioxide is adsorbed in proteins (capsomeres) of viruses, where it reacts with ribonucleic acid. Previously, the effectiveness of chlorine dioxide was explored against coxsackievirus B5, bacteriophage $\mathrm{f}$, human rotavirus, poliovirus 1, simian rotavirus and echovirus 1. Chlorine dioxide was potent at a wider range of $\mathrm{pH}$, dosing at $1.0 \mathrm{mg} / \mathrm{L}$. Chlorine dioxide has more efficacy than chlorine and ozone towards few viruses. Howbeit, for SARS-CoV, it shows less effectiveness than chlorine (Zhang et al. 2020). Chlorine dioxide can inactivate SARS-CoV adequately after $30 \mathrm{~min}$ of exposure time and at the dose of $40 \mathrm{mg} / \mathrm{L}$. Also, inactivation of murine coronavirus was successful soon after the exposure to chlorine dioxide gas at the dosage of $0.16 \mathrm{ppm} / \mathrm{min}$ (Kim et al. 2016).

\section{Hydrogen peroxide}

In numerous organic treatment techniques, hydrogen peroxide is supplemented as a wellspring of dissolved oxygen in pretreatment of high-quality wastewater where biotreatment may not be pragmatic and in predigestion of wastewaters containing inconsistent levels of toxic substances. The synthetic liquid disinfectant may be preferably utilized because of easy handling, expeditious start-up; however, utilization of hydrogen peroxide for full-scale wastewater treatment is paltry (McDonnell 2014). It is safe, more advantageous oxidizing alternative commonly accessible at the concentration of $3 \%$ which is powerful at combating against microscopic organisms including yeast, bacteria, spores, fungi and viruses. Hydrogen peroxide excessively damages the viral genetic material, lipids and other cell components, as 
the virus is devoid of repair mechanism and thus cannot escape this damage generated by $\mathrm{OH}^{-}$radicals of hydrogen peroxide. Exposure of hydrogen peroxide vapour in the concentration of $20 \mu \mathrm{l}$ to a coronavirus surrogate for nearly 2 to $3 \mathrm{~h}$ on stainless steel consequently reduces the virus load (Goyal et al. 2014). Hydrogen peroxide is regarded risk-free as it produces water and oxygen during dissolution, thereby being a nonpollutant.

\section{Ozone}

Ozone is a reliable, clean oxidizing agent with powerful microbicidal impact against viruses, bacteria and protozoan (Tizaoui 2020). Ozone is successful in obliterating viruses by destroying the viral protein. Microorganisms get inactivated via ozone as it reacts with the cytoplasmic membrane, thereby breaking lipid components at various bond sites (Mecha and Chollom 2020; Zucker et al. 2021). Additionally, during ozone contact with a virus, it yields capsid proteins, protein hydroperoxides and protein hydroxides, generating oxidative stress, for which the virus is incapable of combat. Lately, none of the reports is available on ozone disinfection for wastewater against SARS-CoV-2, despite that it is envisaged to be effective against viruses, as ozonation manifests positive results in disinfecting SARS-CoV-1 (Martínez-Sánchez et al. 2020). The current analysis recommends exploitation of ozone as powerful oxidant against SARS-CoV-2, where it distorts the proteins and lipids of the viral membrane (spike and envelope), specifically tryptophan, oleic acid, methionine cysteine, linoleic acid and arachidonic acid and $\mathrm{N}$-glycopeptides of the spike protein. Viruses display better tolerance mechanism to ozone compared to bacteria. Ozone is a substantial disinfectant which can enhance biological water quality in less time and concentration at higher efficacy.

\section{Effect of environmental factors on transmission, survival and infectivity}

\section{Temperature and humidity}

Seasonal change, a ubiquitous attribute, is associated with several acute infections, and predominantly with viral respiratory ailments (Martinez 2018). For example, influenza recrudescence transpires every winter within the temperate realm. An epidemiological paradigm in the USA manifested that absolute humidity influenced the influenza prevalence (Shaman et al. 2010). Furthermore, an outbreak of severe acute respiratory syndrome (SARS) in China during November 2002, entirely abated by July 2003 (Ma et al. 2020). Case study investigations in Beijing, Hong Kong, Taiyuan and Guangzhou evinced that the severe acute respiratory syndrome virus outbreak was notably associated with temperature variations (Xie and Zhu 2020). Epidemiological data and emerging laboratories indicate that diverse environmental conditions may influence the ongoing COVID-19 pandemic (Brassey et al. 2020). A promulgated laboratory analysis stated that SARS-CoV-2 is significantly stable at $4^{\circ}$ $\mathrm{C}$, however, susceptible to high temperature. The survival time of virus declined to $5 \mathrm{~min}$ when subjected to higher incubation temperature $\left(70^{\circ} \mathrm{C}\right)$. Epidemiological investigations suggest an association between SARS-CoV-2 and environmental parameters, yet the outcome of studies is controversial (Yao et al. 2020). About $1^{\circ} \mathrm{C}$ increase in mean temperature $\left(\sim 3^{\circ} \mathrm{C}\right)$ raised the daily cases of COVID-19 by $4.861 \%$ (Xie and Zhu 2020). A study reported the positive relationship between everyday deaths from COVID-19 and daytime temperature, and a negative relation with relative humidity (Ma et al. 2020). Howbeit, another study stated no association between COVID-19 cases and transmission with temperature in china (Yao et al. 2020). Another finding exhibited that humidity and temperature are inversely correlated with COVID-19 (everyday, fresh cases and deaths). Increase in temperature by $1^{\circ} \mathrm{C}$ lowered the daily new cases by $3.08 \%$ whilst as deaths also declined by $1.19 \%$, whereas $1 \%$ increase in humidity reduced daily new cases by $0.85 \%$ and deaths declined by $0.51 \%$, the aforementioned analysis was done by 196 countries (Wu et al. 2020). Global transmission of SARS-CoV-2 is very rapid; therefore, the impact of meteorological parameters towards the spread of SARSCoV-2 must be examined in order to predict the progression in combating COVID-19, whilst several other factors may influence the advancement of COVID-19 pandemic.

\section{Bioaerosols}

Direct/indirect mode of contact entails the vulnerable individual to touch each other physically, viz. hands contaminated with the virus. Direct mode signifies person-toperson contact spreads the virus between the carrier and susceptible individual scilicet, handshake, whereas, indirect mode indicates transmission through fomite, for instance, virus-contaminated handrail, tissue paper, etcetera. Contrastingly, airborne transmission transpires via distinct modes and demands no physical contact between the individual (infected and susceptible). In comparison, sneezing/coughing virus-laden droplet with the size of $5 \mu \mathrm{m}$ in diameter scatters and targets susceptible hosts. A vulnerable individual inhales evaporated respiratory microscopic bioaerosols, and these tiny droplets $(<5 \mu \mathrm{m})$ remain airborne up to hours (Asadi et al. 2020). Airborne-associated disease investigations prior to COVID-19 pandemic emphasized violent expiratory incidents, viz. sneeze/cough (Lindsley et al. 2013). Numerous infected persons transmitting 
SARS-CoV-2 have mild symptoms or are nonsymptomatic. Various researches reported the transmission of the virus from asymptomatic individuals who tested positive for COVID-19 (Rothe et al. 2020). Asymptomatic carriers usually do not sneeze/cough to some considerable extent, denoting mode of transmission via bioaerosols (Zou et al. 2020). Research executed during the SARS epidemic in 2003 demonstrates that hospitalized individuals infected with SARS release viable virus (aerosols) into the environment (Booth et al. 2005). Reportedly that epidemic was induced by SARS-CoV-1, which is closely associated to the ongoing pandemic (SARS-CoV-2). Both these viruses are not identical. However, research carried out by van Doremalen et al. (2020) revealed that aerosolized SARS-CoV-2 retained in the air for hours and inferred that transmission via fomite and bioaerosols is plausible, as SARS-CoV-2 remains viable in aerosols and various surfaces for hours to several days.

\section{Major challenges}

Sample handling and processing are the critical issues in detection of SARS-CoV-2 which occurs at a low concentration in wastewater and sewage. Several primary data indicate that ribonucleic acid-based polymerase chain reaction test and single-step reverse transcriptase droplet digital polymerase chain reaction can elucidate virus quantification. Such approaches possess significant specificity as well as sensitivity, yet they are laborious, require skilled personnel and take a long time for data processing and analysis. Engrossingly, paper analytical apparatus has appeared as a suitable platform for the cost-effective detection of ribonucleic acid sequences of viral strains. The whole process can be executed via simple folding of paper-based apparatus in different ways devoid of any power supply or supplementary tools; therefore, several time-consuming drawbacks of polymerase chain reaction assays are subdued. This approach was effectively implemented in the determination of malaria parasites from blood samples (Reboud et al. 2019). Also, still there exist many challenges, including the requirement of establishing systemic and reliable quantification protocol for viruses, the availability of inadequate data for executing a quantitative assessment for SARS-CoV-2 exposure pathways ascertaining the half-life of viable SARS-CoV-2 within sewage and setting up a sampling protocol and schedule which would serve as representative of the population. Moreover, the amount of virus shed with faeces by an individual is obscure. Additionally, due to limited global resources, the surveillance of SARS-CoV-2 should be cautiously investigated prior to application as per location facilities and involvement of other measurements.

Scientific research has made remarkable progress towards use of biosensors in SARS-CoV-2 detection, and the consequential challenge persists in surpassing the complications associated with translating pragmatic data promptly into commercially feasible prototypes via industries, thereby addressing intricate regulatory matter obligatory for the clinical setting, particularly during pandemic situations. Howbeit, another notable challenge lingers in technology shift of most biosensors and sophisticated instrumentation. Hands-on expertise from subjects which are radically opposite, including biology and electronics, is often required for operating sensing instruments. The technical drawback is being the adoption of biosensor processing protocols, accuracy and reliability of sensors. Rudimentary science and engineering require the discovery of novel materials which must be physically, chemically and intrinsically stable and pioneer techniques and methods to render more reliability in measurements. There are significant ethical concerns also revolving around these technologies; for instance, ownership, privacy and data confidentiality are highly challenging to tackle in a brief period, resulting in less adoption of technology by society. Howbeit, it is contemplated that early SARS-CoV-2 detection in sewage would signify a noninvasive warning to aware communities towards SARS-CoV-2 contagion (Orive et al. 2020).

\section{Conclusion}

COVID-19 global pandemic has emerged as most challenging global health crisis ever faced humanity. Its nearly uncontrollable transmission in human population across international borders despite aggressive curbing measures has surprised the health agencies and administrative authorities and projected a never expected risk of overloading and subsequent collapse of public health systems. Encouragingly, the affected countries are quick enough to implement control measures at community, public health, transport and economic levels to flatten the curve of the COVID-19 pandemic. SARS-COV-2 is an increasing health risks among human population worldwide, and it is imperative to control the spread of the disease in the present time. Since only limited vaccines and antiviral agents are available, only meticulous preventive measures and implementation can bring some significant triumph in this matter of concern. Presently, we are only equipped with isolation and quarantine measures being employed throughout most of the world and hence an urgent need is realized to reduce direct and indirect contact (through contaminated object or surface) or close contact with an infected person to flatten the curve of the pandemic. The very imperative thing is about the testing process, the number of tests done regularly, the rate of positivity and whether this number of positive cases stays steady or erratic. Currently, clearcut and straightforward methods are available for the detection of the virus in the 
wastewater samples. However, the use of parameters (for instance, spiking the sample with an animal virus with a structure similar to the target pathogen before concentration) is highly recommended. The most widely used reverse transcriptase polymerase chain reaction techniques provide quick viral ribonucleic acid quantification, but, the primers and probes should be selected cautiously.

To conclude, considering the paramount challenges and threats to human health and survival due to SARS-CoV-2 pandemic, there is an urgent need for research collaborations, data sharing and synergistic vaccine development efforts at war scale. At the same time, emphasis towards development of availability of rapid, cost-effective, sensitive, portable and early diagnostic tools is equally essential. Detection of SARS-CoV-2 from wastewater and sewage in municipal wastewater treatment plants can accelerate the COVID-19 diagnosis at mass scale even before clinical diagnostic testing can reach every single person. Therefore, continuous monitoring of COVID-19 threat in sewage and wastewater along with environmental monitoring of public places and development of better suited disinfection methods will hold promise to control the spread and threat of COVID-19 global pandemic. It can be safely concluded that the technology advancements in the areas of viral detection and disinfection will facilitate better preparedness of scientific community and healthcare organization to tackle possible future biological threats and viral pandemics.

Acknowledgements Simranjeet Singh is thankful to the Interdisciplinary Centre for Water Research (IcWaR), Indian Institute of Sciences, Bangalore, for the financial assistance (IOE-IISc Fellowship No. IE/ REAC-20-0134) and for providing excellent laboratory and library facilities.

\section{Compliance with ethical standards}

Conflict of interest The authors declare that they have no conflict of interest.

\section{References}

Adriaenssens EM, Farkas K, Harrison C, Jones DL, Allison HE, McCarthy AJ (2018) Viromic analysis of wastewater input to a river catchment reveals a diverse assemblage of RNA viruses. mSystems. https://doi.org/10.1128/msystems.00025-18

Ahmed W, Angel N, Edson J, Bibby K, Bivins A, O'Brien JW, Choi PM, Kitajima M, Simpson SL, Li J, Tscharke B, Verhagen R, Smith WJM, Zaugg J, Dierens L, Hugenholtz P, Thomas KV, Mueller JF (2020) First confirmed detection of SARS-CoV-2 in untreated wastewater in Australia: A proof of concept for the wastewater surveillance of COVID-19 in the community. Sci Total Environ 728:138764. https://doi.org/10.1016/j.scito tenv.2020.138764

Alpaslan Kocamemi B, Kurt H, Sait A, Sarac F, Saatci AM, Pakdemirli B (2020). SARS-CoV-2 detection in Istanbul wastewater treatment plant sludges. medRxiv 2020.05.12.20099358. https:// doi.org/10.1101/2020.05.12.20099358

Asadi S, Bouvier N, Wexler AS, Ristenpart WD (2020) The coronavirus pandemic and aerosols: Does COVID-19 transmit via expiratory particles? Aerosol Sci Technol. https://doi. org/10.1080/02786826.2020.1749229

Balboa S, Mauricio-Iglesias M, Rodríguez S, Martínez-Lamas L, Vasallo F, Regueiro B, Lema J (2020) The fate of SARS$\mathrm{CoV}-2$ in wastewater treatment plants points out the sludge line as a suitable spot for incidence monitoring. medRxiv 2020.05.25.20112706. https://doi.org/10.1101/2020.05.25.20112 706

Bar Or I, Yaniv K, Shagan M, Ozer E, Erster O, Mendelson E, Mannasse B, Shirazi R, Kramarsky-Winter E, Nir O, Abu-Ali H, Ronen Z, Rinott E, Lewis Y, Friedler EF, Paitan Y, Bitkover E, Berchenko Y, Kushmaro A (2020) Regressing SARSCoV-2 sewage measurements onto COVID-19 burden in the population: a proof-of-concept for quantitative environmental surveillance. medRxiv 2020.04.26.20073569. https://doi. org/10.1101/2020.04.26.20073569

Bofill-Mas S, Rusiñol M (2020) Recent trends on methods for the concentration of viruses from water samples. Curr Opin Environ Sci Heal. https://doi.org/10.1016/j.coesh.2020.01.006

Booth TF, Kournikakis B, Bastien N, Ho J, Kobasa D, Stadnyk L, Li Y, Spence M, Paton S, Henry B, Mederski B, White D, Low DE, McGeer A, Simor A, Vearncombe M, Downey J, Jamieson FB, Tang P, Plummer F (2005) Detection of airborne severe acute respiratory syndrome (SARS) coronavirus and environmental contamination in sars outbreak units. J Infect Dis 191:1472-1477. https://doi.org/10.1086/429634

Brassey J, Heneghan C, Mahtani KR, Aronson JK (2020) Do weather conditions influence the transmission of the coronavirus (SARSCoV-2). CEMB. https://www.cemb.net/oxford-covid-19

Canh VD, Kasuga I, Furumai H, Katayama H (2019) Viability RTqPCR combined with sodium deoxycholate pre-treatment for selective quantification of infectious viruses in drinking water samples. Food Environ Virol 11:40-51. https://doi. org/10.1007/s12560-019-09368-2

Chan JFW, Yuan S, Kok KH, To KKW, Chu H, Yang J, Xing F, Liu J, Yip CCY, Poon RWS, Tsoi HW, Lo SKF, Chan KH, Poon VKM, Chan WM, Ip JD, Cai JP, Cheng VCC, Chen H, Hui CKM, Yuen KY (2020) A familial cluster of pneumonia associated with the 2019 novel coronavirus indicating personto-person transmission: a study of a family cluster. Lancet 395:514-523. https://doi.org/10.1016/S0140-6736(20)30154-9

Chen Y, Chen L, Deng Q, Zhang G, Wu K, Ni L, Yang Y, Liu B, Wang W, Wei C, Yang J, Ye G, Cheng Z (2020) The presence of SARS-CoV-2 RNA in the feces of COVID-19 patients. J Med Virol 92:833-840. https://doi.org/10.1002/jmv.25825

Chen B, Jia P, Han J (2021) Role of indoor aerosols for COVID-19 viral transmission: a review. Environ Chem Lett. https://doi. org/10.1007/s10311-020-01174-8

Choi JR (2020) Development of point-of-care biosensors for COVID-19. Front Chem 8:517. https://doi.org/10.3389/fchem .2020 .00517

Choi H, Chatterjee P, Lichtfouse E, Martel JA, Hwang M, Jinadatha C, Sharma VK (2021) Classical and alternative disinfection strategies to control the COVID-19 virus in healthcare facilities: a review. Environ Chem Lett. https://doi.org/10.1007/ s10311-021-01180-4

Chollom M, Rathilal S, Swalaha F, Bakare B, Tetteh E (2020) Removal of antibiotics during the anaerobic digestion of slaughterhouse wastewater. Int J Sustain Dev Plan 15:335-342. https://doi.org/10.18280/ijsdp.150310

Corman VM, Landt O, Kaiser M, Molenkamp R, Meijer A, Chu DK, Bleicker T, Brünink S, Schneider J, Schmidt ML, Mulders 
DG, Haagmans BL, van der Veer B, van den Brink S, Wijsman L, Goderski G, Romette J-L, Ellis J, Zambon M, Peiris M, Goossens H, Reusken C, Koopmans MP, Drosten C (2020) Detection of 2019 novel coronavirus (2019-nCoV) by real-time RT-PCR. Eurosurveillance 25:2000045. https://doi. org/10.2807/1560-7917.ES.2020.25.3.2000045

Crini G, Lichtfouse E (2019) Advantages and disadvantages of techniques used for wastewater treatment. Environ Chem Lett 17:145-155. https://doi.org/10.1007/s10311-018-0785-9

Cuerda-Correa EM, Alexandre-Franco MF, Fernández-González C (2019) Advanced oxidation processes for the removal of antibiotics from water. An overview. Water 12:102. https://doi. org/10.3390/w12010102

Dai H, Han J, Lichtfouse E (2020) Who is running faster, the virus or the vaccine? Environ Chem Lett 18:1761-1766. https://doi. org/10.1007/s10311-020-01110-w

Ettayebi K, Crawford SE, Murakami K, Broughman JR, Karandikar U, Tenge VR, Neill FH, Blutt SE, Zeng XL, Qu L, Kou B, Opekun AR, Burrin D, Graham DY, Ramani S, Atmar RL, Estes MK (2016) Replication of human noroviruses in stem cell-derived human enteroids. Science 353:1387-1393. https ://doi.org/10.1126/science.aaf5211

Farkas K, Hillary LS, Malham SK, McDonald JE, Jones DL (2020a) Wastewater and public health: the potential of wastewater surveillance for monitoring COVID-19. Curr Opin Environ Sci Heal. https://doi.org/10.1016/j.coesh.2020.06.001

Farkas K, Mannion F, Hillary LS, Malham SK, Walker DI (2020b) Emerging technologies for the rapid detection of enteric viruses in the aquatic environment. Curr Opin Environ Sci Heal. https://doi.org/10.1016/j.coesh.2020.01.007

Gostin LO, Friedman EA, Wetter SA (2020) Responding to Covid19: how to navigate a public health emergency legally and ethically. Hastings Cent Rep 50:8-12. https://doi.org/10.1002/ hast. 1090

Goyal SM, Chander Y, Yezli S, Otter JA (2014) Evaluating the virucidal efficacy of hydrogen peroxide vapour. J Hosp Infect 86:255-259. https://doi.org/10.1016/j.jhin.2014.02.003

Gray E, Turbé V, Lawson V, Page R, Cook ZC (2018) Ultra-rapid, sensitive and specific digital diagnosis of HIV with a dualchannel SAW biosensor in a pilot clinical study. nature.com

Han JH, Lee D, Chew CHC, Kim T, Pak JJ (2016) A multi-virus detectable microfluidic electrochemical immunosensor for simultaneous detection of $\mathrm{H} 1 \mathrm{~N} 1, \mathrm{H} 5 \mathrm{~N} 1$, and $\mathrm{H} 7 \mathrm{~N} 9$ virus using $\mathrm{ZnO}$ nanorods for sensitivity enhancement. Sens Actuators B Chem 228:36-42. https://doi.org/10.1016/j.snb.2015.07.068

Hata A, Kitajima M, Haramoto E, Lee S (2018) Next-generation amplicon sequencing identifies genetically diverse human astroviruses, including recombinant strains, in environmental waters. nature.com

He S, Han J, Lichtfouse E (2021) Backward transmission of COVID19 from humans to animals may propagate reinfections and induce vaccine failure. Environ Chem Lett. https://doi. org/10.1007/s10311-020-01140-4

Hirvonen JJ (2019) Comparison of three multiplex real-time PCR assays for detection of enteric viruses in patients with diarrhea. Eur J Clin Microbiol Infect Dis 38:241-244. https://doi. org/10.1007/s10096-018-3418-0

Holshue ML, DeBolt C, Lindquist S, Lofy KH, Wiesman J, Bruce H, Spitters C, Ericson K, Wilkerson S, Tural A, Diaz G, Cohn A, Fox L, Patel A, Gerber SI, Kim L, Tong S, Lu X, Lindstrom S, Pallansch MA, Weldon WC, Biggs HM, Uyeki TM, Pillai SK (2020) First case of 2019 novel coronavirus in the United States. N Engl J Med 382:929-936. https://doi.org/10.1056/ nejmoa2001191
Hønsvall BK, Robertson LJ (2017) From research lab to standard environmental analysis tool: Will NASBA make the leap? Water Res. https://doi.org/10.1016/j.watres.2016.11.052

Huang X, Lin X, Urmann K, Li L, Xie X, Jiang S, Hoffmann MR (2018) Smartphone-based in-gel loop-mediated isothermal amplification (gLAMP) system enables rapid coliphage MS2 quantification in environmental waters. Environ Sci Technol 52:6399-6407. https://doi.org/10.1021/acs.est.8b00241

Huang X, Chen J, Yao G, Guo Q, Wang J, Liu G (2019) A TaqManprobe-based multiplex real-time RT-qPCR for simultaneous detection of porcine enteric coronaviruses. Appl Microbiol Biotechnol 103:4943-4952. https://doi.org/10.1007/s0025 3-019-09835-7

Ishikawa FN, Chang HK, Curreli M, Liao HI, Olson CA, Chen PC, Znang R, Roberts RW, Thompson ME, Zhou C (2009) Labelfree, electrical detection of the SARS virusN-Protein with nanowire biosensors utilizing antibody mimics as capture probes. ACS nano 3(5):1219-1224

Jahne MA, Brinkman NE, Keely SP, Zimmerman BD, Wheaton EA, Garland JL (2020) Droplet digital PCR quantification of norovirus and adenovirus in decentralized wastewater and graywater collections: Implications for onsite reuse. Water Res 169:115213. https://doi.org/10.1016/j.watres.2019.115213

Jones MK, Grau KR, Costantini V, Kolawole AO, de Graaf M, Freiden P, Graves CL, Koopmans M, Wallet SM, Tibbetts SA, Schultz-Cherry S, Wobus CE, Vinj J, Karst SM (1939) Human norovirus culture in B cells. Nat Protoc. https://doi. org/10.1038/nprot.2015.121

Jyoti A, Tomar RS (2017) Detection of pathogenic bacteria using nanobiosensors. Environ Chem Lett 15:1-6. https://doi.org/10.1007/ s10311-016-0594-y

Kalyani N, Goel S, Jaiswal S (2020) On-site sensing of pesticides using point-of-care biosensors: a review. Environ Chem Lett. https:// doi.org/10.1007/s10311-020-01070-1

Kamikawa TL, Mikolajczyk MG, Kennedy M, Zhong L, Zhang P, Setterington EB, Scott DE, Alocilja EC (2012) Pandemic influenza detection by electrically active magnetic nanoparticles and surface plasmon resonance. IEEE Trans Nanotechnol 11:88-96. https://doi.org/10.1109/TNANO.2011.2157936

Kataki S, Chatterjee S, Vairale MG, Sharma S, Dwivedi SK (2020) Concerns and strategies for wastewater treatment during COVID-19 pandemic to stop plausible transmission. Resour Conserv Recycl 164:105156. https://doi.org/10.1016/j.resco nrec.2020.105156

Kim J, Shin B-H, Song KJ, Kim JR, Kim K (2016) Virucidal effect of gaseous chlorine dioxide on murine coronavirus A59. AJOU Open Repos

Kim JY, Ko J, Kim Y, Kim YJ, Kim JM, Chung Y (2019) Viral load kinetics of SARS-CoV-2 infection in first. J Korean Med Sci 35:e86

Kumar M, Patel AK, Shah AV, Raval J, Rajpara N, Joshi M, Joshi CG (2020) First proof of the capability of wastewater surveillance for COVID-19 in India through detection of genetic material of SARS-CoV-2. Sci Total Environ 746:141326. https://doi. org/10.1016/j.scitotenv.2020.141326

La Rosa G, Iaconelli M, Mancini P, Bonanno Ferraro G, Veneri C, Bonadonna L, Lucentini L, Suffredini E (2020) First detection of SARS-CoV-2 in untreated wastewaters in Italy. Sci Total Environ 736:139652. https://doi.org/10.1016/j.scitotenv.2020.139652

Lahrich S, Laghrib F, Farahi A, Bakasse M, Saqrane S, El Mhammedi MA (2020) Review on the contamination of wastewater by COVID-19 virus: Impact and treatment. Sci Total Environ 751:142325. https://doi.org/10.1016/j.scitotenv.2020.142325

Langlet J, Kaas L, Croucher D, Hewitt J (2018) Effect of the shellfish proteinase $\mathrm{K}$ digestion method on norovirus capsid integrity. 
Food Environ Virol 10:151-158. https://doi.org/10.1007/s1256 0-018-9336-6

Larsen DA, Wigginton KR (2020) Tracking COVID-19 with wastewater. Nat Biotechnol 38:1151-1153. https://doi.org/10.1038/ s41587-020-0690-1

Layqah LA, Eissa S (2019) An electrochemical immunosensor for the corona virus associated with the Middle East respiratory syndrome using an array of gold nanoparticle-modified carbon electrodes. Microchim Acta 186:1-10. https://doi.org/10.1007/ s00604-019-3345-5

Leblanc D, Gagné MJ, Poitras É, Brassard J (2019) Persistence of murine norovirus, bovine rotavirus, and hepatitis A virus on stainless steel surfaces, in spring water, and on blueberries. Food Microbiol 84:103257. https://doi.org/10.1016/j.fm.2019.103257

Lee HW, Lee HM, Yoon SR, Kim SH, Ha JH (2018) Pretreatment with propidium monoazide/sodium lauroyl sarcosinate improves discrimination of infectious waterborne virus by RT-qPCR combined with magnetic separation. Environ Pollut 233:306-314. https://doi.org/10.1016/j.envpol.2017.10.081

Leifels M, Shoults D, Wiedemeyer A, Ashbolt NJ, Sozzi E, Hagemeier A, Jurzik L (2019) Capsid Integrity qPCR - an azo-dye based and culture-independent approach to estimate adenovirus infectivity after disinfection and in the aquatic environment. Water 11:1196. https://doi.org/10.3390/w11061196

Li Y, Hong M, Lin Y, Bin Q, Lin Z, Cai Z, Chen G (2012) Highly sensitive electrochemical immunoassay for H1N1 influenza virus based on copper-mediated amplification. Chem Commun 48:6562-6564. https://doi.org/10.1039/c2cc31990j

Li C, Yang J, Zhang L, Li S, Yuan Y, Xiao X, Fan X, Song C (2020) Carbon-based membrane materials and applications in water and wastewater treatment: a review. Environ Chem Lett. https://doi. org/10.1007/s10311-020-01112-8

Lindsley WG, Reynolds JS, Szalajda JV, Noti JD, Beezhold DH (2013) A cough aerosol simulator for the study of disease transmission by human cough-generated aerosols. Aerosol Sci Technol 47:937-944. https://doi.org/10.1080/02786826.2013.803019

Lu G, Hu Y, Wang Q, Qi J, Gao F, Li Y, Zhang Y, Zhang W, Yuan Y, Bao J, Zhang B, Shi Y, Yan J, Gao GF (2013) Molecular basis of binding between novel human coronavirus MERS-CoV and its receptor CD26. Nature 500:227-231. https://doi.org/10.1038/ nature 12328

Ma R, Nanotechnology R.O.-N. (2019) 2019. Applications of nanolasers. nature.com

Ma Y, Zhao Y, Liu J, He X, Wang B, Fu S, Yan J, Niu J, Zhou J, Luo B (2020) Effects of temperature variation and humidity on the death of COVID-19 in Wuhan. China Sci Total Environ 724:138226. https://doi.org/10.1016/j.scitotenv.2020.138226

Malecka K, Stachyra A, Góra-Sochacka A, Sirko A, Zagórski-Ostoja W, Radecka H, Radecki J (2016) Electrochemical genosensor based on disc and screen printed gold electrodes for detection of specific DNA and RNA sequences derived from Avian Influenza Virus H5N1. Sens Actuators B Chem 224:290-297. https://doi. org/10.1016/j.snb.2015.10.044

Mao K, Zhang H, Yang Z (2020) Can a paper-based device trace COVID-19 sources with wastewater-based epidemiology? Environ Sci Technol. https://doi.org/10.1021/acs.est.0c01174

Martinez ME (2018) The calendar of epidemics: Seasonal cycles of infectious diseases. PLOS Pathog 14:e1007327. https://doi. org/10.1371/journal.ppat.1007327

Martínez-Sánchez G, Schwartz A, Di Donna V (2020) Potential cytoprotective activity of ozone therapy in SARS-CoV-2/COVID-19. Antioxidants 9:389. https://doi.org/10.3390/antiox9050389

McDonnell G (2014) The use of hydrogen peroxide for disinfection and sterilization applications. In: PATAI'S chemistry of functional groups. Wiley, Chichester, UK, pp 1-34. https://doi. org/10.1002/9780470682531.pat0885
Mecha AC, Chollom MN (2020) Photocatalytic ozonation of wastewater: a review. Environ Chem Lett 18:1491-1507. https://doi. org/10.1007/s10311-020-01020-x

Medema G, Heijnen L, Elsinga G, Italiaander R, Brouwer A (2020a) Presence of SARS-coronavirus-2 RNA in sewage and correlation with reported COVID-19 prevalence in the early stage of the epidemic in the Netherlands. Environ Sci Technol Lett 7:511-516. https://doi.org/10.1021/acs.estlett.0c00357

Medema G, Heijnen L, Elsinga G, Italiaander R, Brouwer A (2020) Presence of SARS-coronavirus-2 in sewage. medRxiv 2020.03.29.20045880. https://doi.org/10.1101/2020.03.29.20045 880

Monteiro S, Santos R (2018) Enzymatic and viability RT-qPCR assays for evaluation of enterovirus, hepatitis A virus and norovirus inactivation: Implications for public health risk assessment. J Appl Microbiol 124:965-976. https://doi.org/10.1111/jam.13568

Nasseri B, Soleimani N, Rabiee N, Kalbasi A, Karimi M, Hamblin MR (2018) Point-of-care microfluidic devices for pathogen detection. Biosens Bioelectron. https://doi.org/10.1016/j.bios.2018.05.050

Nemudryi A, Nemudraia A, Wiegand T, Surya K, Buyukyoruk M, Cicha C, Vanderwood KK, Wilkinson R, Wiedenheft B (2020) Temporal detection and phylogenetic assessment of SARSCoV-2 in municipal wastewater. Cell Rep Med 1:100098. https ://doi.org/10.1016/j.xcrm.2020.100098

Ng SC, Chan FKL, Chan PKS (2020) Screening FMT donors during the COVID-19 pandemic: a protocol for stool SARS-CoV-2 viral quantification. Lancet Gastroenterol Hepatol. https://doi. org/10.1016/S2468-1253(20)30124-2

O'Bannon DJ (2020) Women in water quality: investigations by prominent female engineers. Google books. Springer, Berlin

Orive G, Lertxundi U, Barcelo D (2020) Early SARS-CoV-2 outbreak detection by sewage-based epidemiology. Sci Total Environ 732:139298. https://doi.org/10.1016/j.scitotenv.2020.139298

Pang X, Qiu Y, Gao T, Zurawell R, Neumann NF, Craik S, Lee BE (2019) Prevalence, levels and seasonal variations of human enteric viruses in six major rivers in Alberta. Canada Water Res 153:349-356. https://doi.org/10.1016/j.watres.2019.01.034

Parihar A, Ranjan P, Sanghi SK, Srivastava AK, Khan R (2020) Point-of-care biosensor-based diagnosis of COVID-19 holds promise to combat current and future pandemics. ACS Appl Biol Mater 4:3458. https://doi.org/10.1021/acsabm.0c01083

Peccia J, Zulli A, Brackney D, Grubaugh N, Kaplan E Casanovas-Massana A, Ko A, Malik A, Wang D, Wang M, Warren J, Weinberger D, Omer S (2020) SARSCoV-2 RNA concentrations in primary municipal sewage sludge as a leading indicator of COVID-19 outbreak dynamics. medRxiv 2020.05.19.20105999. https://doi. org/10.1101/2020.05.19.20105999

Prem K, Liu Y, Russell TW, Kucharski AJ, Eggo RM, Davies N, Flasche S, Clifford S, Pearson CAB, Munday JD, Abbott S, Gibbs H, Rosello A, Quilty BJ, Jombart T, Sun F, Diamond C, Gimma A, van Zandvoort K, Funk S, Jarvis CI, Edmunds WJ, Bosse NI, Hellewell J, Jit M, Klepac P (2020) The effect of control strategies to reduce social mixing on outcomes of the COVID-19 epidemic in Wuhan, China: a modelling study. Lancet Public Heal 5:e261-e270. https://doi.org/10.1016/S2468 -2667(20)30073-6

Qiu G, Gai Z, Tao Y, Schmitt J, Kullak-Ublick GA, Wang J (2020) Dual-functional plasmonic photothermal biosensors for highly accurate severe acute respiratory syndrome coronavirus 2 detection. ACS Nano 14:5268-5277. https://doi.org/10.1021/acsna no.0c02439

Rames EK, Macdonald J (2019) Rapid assessment of viral water quality using a novel recombinase polymerase amplification test for human adenovirus. Appl Microbiol Biotechnol 103:8115-8125. https://doi.org/10.1007/s00253-019-10077-w 
Randazzo W, Vasquez-García A, Aznar R, Sánchez G (2018) Viability RT-qPCR to distinguish between HEV and HAV with intact and altered capsids. Front Microbiol 9:1973. https://doi.org/10.3389/ fmicb.2018.01973

Randazzo W, Truchado P, Cuevas-Ferrando E, Simón P, Allende A, Sánchez G (2020) SARS-CoV-2 RNA in wastewater anticipated COVID-19 occurrence in a low prevalence area. Water Res 181:115942. https://doi.org/10.1016/j.watres.2020.115942

Randazzo W, Cuevas-Ferrando E, Sanjuán R, Domingo-Calap P, Sánchez G (2020) Metropolitan wastewater analysis for COVID19 epidemiological surveillance. SSRN Electron J. https://doi. org/10.2139/ssrn.3586696

Rang FJ, Kloosterman WP, de Ridder J (2018) From squiggle to basepair: computational approaches for improving nanopore sequencing read accuracy. Genome Biol. https://doi.org/10.1186/s1305 9-018-1462-9

Reboud J, Xu G, Garrett A, Adriko M, Yang Z, Tukahebwa EM, Rowell C, Cooper JM (2019) Paper-based microfluidics for DNA diagnostics of malaria in low resource underserved rural communities. Proc Natl Acad Sci USA 116:4834-4842. https://doi. org/10.1073/pnas.1812296116

Rodriguez GA, Markov P, Cartwright AP, Choudhury MH, Afzal FO, Cao T, Halimi SI, Retterer ST, Kravchenko II, Weiss SM (2019) Photonic crystal nanobeam biosensors based on porous silicon. Opt Express 27:9536. https://doi.org/10.1364/oe.27.009536

Rothan HA, Byrareddy SN (2020) The epidemiology and pathogenesis of coronavirus disease (COVID-19) outbreak. J Autoimmun. https://doi.org/10.1016/j.jaut.2020.102433

Rothe C, Schunk M, Sothmann P, Bretzel G, Froeschl G, Wallrauch C, Zimmer T, Thiel V, Janke C, Guggemos W, Seilmaier M, Drosten C, Vollmar P, Zwirglmaier K, Zange S, Wölfel R, Hoelscher M (2020) Transmission of 2019-nCoV infection from an asymptomatic contact in Germany. N Engl J Med 382:970-971. https:// doi.org/10.1056/nejmc2001468

Sato S, Hisaie K, Kurokawa S, Suzuki A, Sakon N, Uchida Y, Yuki Y, Kiyono H (2019) Human norovirus propagation in human induced pluripotent stem cell-derived intestinal epithelial cells. CMGH 7:686-688.e5. https://doi.org/10.1016/j.jcmgh .2018 .11 .001

Schilling KB, DeGrasse J, Woods JW (2018) The influence of food matrices on aptamer selection by SELEX (systematic evolution of ligands by exponential enrichment) targeting the norovirus P-domain. Food Chem 258:129-136. https://doi.org/10.1016/j. foodchem.2018.03.054

Sedji MI, Varbanov M, Meo M, Colin M, Mathieu L, Bertrand I (2018) Quantification of human adenovirus and norovirus in river water in the north-east of France. Environ Sci Pollut Res 25:3049730507. https://doi.org/10.1007/s11356-018-3045-4

Seo G, Lee G, Kim MJ, Baek SH, Choi M, Ku KB, Lee CS, Jun S, Park D, Kim HG, Kim SJ, Lee JO, Kim BT, Park EC, Kim SI (2020) Rapid detection of COVID-19 causative virus (SARS-CoV-2) in human nasopharyngeal swab specimens using field-effect transistor-based biosensor. ACS Nano 14:5135-5142. https:// doi.org/10.1021/acsnano.0c02823

Shaman J, Pitzer VE, Viboud C, Grenfell BT, Lipsitch M (2010) Absolute humidity and the seasonal onset of influenza in the continental United States. PLoS Biol 8:e1000316. https://doi.org/10.1371/ journal.pbio. 1000316

Sharma VK, Jinadatha C, Lichtfouse E (2020) Environmental chemistry is most relevant to study coronavirus pandemics. Environ Chem Lett 18:993-996. https://doi.org/10.1007/s10311-02001017-6

Shen F, Cheng Y, Xie Y, Yu H, Yao W, Li HW, Guo Y, Qian H (2019) DNA-silver nanocluster probe for norovirus RNA detection based on changes in secondary structure of nucleic acids. Anal Biochem 583:113365. https://doi.org/10.1016/j.ab.2019.113365
Shu Z, Singh A, Klamerth N, McPhedran K, Bolton JR, Belosevic M, Gamal El-Din M (2016) Pilot-scale UV/H 2 O 2 advanced oxidation process for municipal reuse water: assessing micropollutant degradation and estrogenic impacts on goldfish (Carassius auratus L.). Water Res 101:157-166. https://doi.org/10.1016/j. watres.2016.05.079

Sims N, Kasprzyk-Hordern B (2020) Future perspectives of wastewater-based epidemiology: monitoring infectious disease spread and resistance to the community level. Environ Int. https://doi. org/10.1016/j.envint.2020.105689

Socorro-Leránoz AB, Santano D, Del Villar I, Matias IR (2019) Trends in the design of wavelength-based optical fibre biosensors (20082018). Biosens Bioelectron X. https://doi.org/10.1016/j.biosx .2019 .100015

Stoian IA, Iacob BC, Dudaș CL, Barbu-Tudoran L, Bogdan D, Marian IO, Bodoki E, Oprean R (2020) Biomimetic electrochemical sensor for the highly selective detection of azithromycin in biological samples. Biosens Bioelectron 155:112098. https://doi. org/10.1016/j.bios.2020.112098

Sun S, Han J (2020) Open defecation and squat toilets, an overlooked risk of fecal transmission of COVID-19 and other pathogens in developing communities. Environ Chem Lett. https://doi. org/10.1007/s10311-020-01143-1

Syu Y-C, Hsu W-E, Lin C-T (2018) Review-field-effect transistor biosensing: devices and clinical applications. ECS J Solid State Sci Technol 7:Q3196-Q3207. https://doi.org/10.1149/2.0291807jss

Takemura K, Adegoke O, Takahashi N, Kato T, Li TC, Kitamoto N, Tanaka T, Suzuki T, Park EY (2017) Versatility of a localized surface plasmon resonance-based gold nanoparticle-alloyed quantum dot nanobiosensor for immunofluorescence detection of viruses. Biosens Bioelectron 89:998-1005. https://doi. org/10.1016/j.bios.2016.10.045

Tian P, Yang D, Shan L, Li Q, Liu D, Wang D (2018) Estimation of human norovirus infectivity from environmental water samples by in situ capture RT-qPCR method. Food Environ Virol 10:2938. https://doi.org/10.1007/s12560-017-9317-1

Tizaoui C (2020) Ozone: a potential oxidant for COVID-19 virus (SARS-CoV-2). Ozone Sci Eng 42:378-385. https://doi. org/10.1080/01919512.2020.1795614

van Doremalen N, Bushmaker T, Morris DH, Holbrook MG, Gamble A, Williamson BN, Tamin A, Harcourt JL, Thornburg NJ, Gerber SI, Lloyd-Smith JO, de Wit E, Munster VJ (2020) Aerosol and Surface Stability of SARS-CoV-2 as Compared with SARSCoV-1. N Engl J Med 382(16):1564-1567

Van Dycke J, Ny A, Conceição-Neto N, Maes J, Hosmillo M, Cuvry A, Goodfellow I, Nogueira TC, Verbeken E, Matthijnssens J, de Witte P, Neyts J, Rocha-Pereira J (2019) A robust human norovirus replication model in zebrafish larvae. PLOS Pathog 15:e1008009. https://doi.org/10.1371/journal.ppat.1008009

Verma ML, Rani V (2020) Biosensors for toxic metals, polychlorinated biphenyls, biological oxygen demand, endocrine disruptors, hormones, dioxin, phenolic and organophosphorus compounds: a review. Environ Chem Lett. https://doi.org/10.1007/s10311-02001116-4

Walker DI, McQuillan J, Taiwo M, Parks R, Stenton CA, Morgan H, Mowlem MC, Lees DN (2017) A highly specific Escherichia coli qPCR and its comparison with existing methods for environmental waters. Water Res 126:101-110. https://doi.org/10.1016/j. watres.2017.08.032

Wang X, Han J, Lichtfouse E (2020) Unprotected mothers and infants breastfeeding in public amenities during the COVID19 pandemic. Environ Chem Lett 18:1447-1450. https://doi. org/10.1007/s10311-020-01054-1

Weerathunge P, Ramanathan R, Torok VA, Hodgson K, Xu Y, Goodacre R, Behera BK, Bansal V (2019) Ultrasensitive colorimetric detection of murine norovirus using nanozyme aptasensor. 
Anal Chem 91:3270-3276. https://doi.org/10.1021/acs.analc hem. $8 \mathrm{~b} 03300$

WHO (2021). World Health Organization. https://www.who.int/ emergencies/diseases/novel-coronavirus-2019 (Accessed on 09/01/2021)

Woelfel R, Corman VM, Guggemos W, Seilmaier M, Zange S, Mueller M, Niemeyer D, Vollmar P, Rothe C, Hoelscher M, Bleicker T, Bruenink S, Schneider J, Ehmann R, Zwirglmaier K, Drosten C, Wendtner C (2020) Clinical presentation and virological assessment of hospitalized cases of coronavirus disease 2019 in a travel-associated transmission cluster. medRxiv 2020.03.05.20030502. https://doi.org/10.1101/2020.03.05.20030 502

Wu Y, Jing W, Liu J, Ma Q, Yuan J, Wang Y, Du M, Liu M (2020) Effects of temperature and humidity on the daily new cases and new deaths of COVID-19 in 166 countries. Sci Total Environ 729:139051. https://doi.org/10.1016/j.scitotenv.2020.139051

Wurtzer S, Marechal V, Mouchel J, Maday Y, Teyssou R, Richard E, Almayrac J, Moulin L (2020) Evaluation of lockdown impact on SARS-CoV-2 dynamics through viral genome quantification in Paris wastewaters. medRxiv

Xie J, Zhu Y (2020) Association between ambient temperature and COVID-19 infection in 122 cities from China. Sci Total Environ 724:138201. https://doi.org/10.1016/j.scitotenv.2020.138201

Yao Y, Pan J, Liu Z, Meng X, Wang W, Kan H, Wang W (2020) No association of COVID-19 transmission with temperature or UV radiation in Chinese cities. Eur Respir J. https://doi. org/10.1183/13993003.00517-2020

Young BE, Ong SWX, Kalimuddin S, Low JG, Tan SY, Loh J, Ng OT, Marimuthu K, Ang LW, Mak TM, Lau SK, Anderson DE, Chan KS, Tan TY, Ng TY, Cui L, Said Z, Kurupatham L, Chen MIC, Chan M, Vasoo S, Wang LF, Tan BH, Lin RTP, Lee VJM, Leo YS, Lye DC (2020) Epidemiologic features and clinical course of patients infected with SARS-CoV-2 in Singapore. JAMA J Am Med Assoc 323:1488-1494. https://doi.org/10.1001/ jama.2020.3204

Yurick D, Khoury G, Clemens B, Loh L, Pham H, Kedzierska K, Einsiedel L, Purcell D (2019) Multiplex droplet digital PCR assay for quantification of human T-cell leukemia virus type 1 subtype $\mathrm{C}$ DNA proviral load and $\mathrm{T}$ cells from blood and respiratory exudates sampled in a remote setting. J Clin Microbiol. https:// doi.org/10.1128/JCM.01063-18
Zhang GJ, Zhang L, Huang MJ, Luo ZHH, Tay GKI, Lim EJA, Kang TG, Chen Y (2010) Silicon nanowire biosensor for highly sensitive and rapid detection of Dengue virus. Sens Actuators B Chem 146:138-144. https://doi.org/10.1016/j.snb.2010.02.021

Zhang J, Borth W, Lin B, Melzer M, Shen H, Pu X, Sun D, Nelson S, Hu J (2018) Multiplex detection of three banana viruses by reverse transcription loop-mediated isothermal amplification (RT-LAMP). Trop Plant Pathol 43:543-551. https://doi. org/10.1007/s40858-018-0257-6

Zhang H, Xu Y, Fohlerova Z, Chang H, Iliescu C, Neuzil P (2019) LAMP-on-a-chip: revising microfluidic platforms for loop-mediated DNA amplification. TrAC Trends Anal Chem. https://doi. org/10.1016/j.trac.2019.01.015

Zhang D, Ling H, Huang X, Li J, Li W, Yi C, Zhang T, Jiang Y, He Y, Deng S, Zhang X, Wang X, Liu Y, Li G, Qu J (2020) Potential spreading risks and disinfection challenges of medical wastewater by the presence of severe acute respiratory syndrome coronavirus 2 (SARS-CoV-2) viral RNA in septic tanks of Fangcang Hospital. Sci Total Environ 741:140445. https://doi. org/10.1016/j.scitotenv.2020.140445

Zhu N, Zhang D, Wang W, Li X, Yang B, Song J, Zhao X, Huang B, Shi W, Lu R, Niu P, Zhan F, Ma X, Wang D, Xu W, Wu G, Gao GF, Tan W (2020) A novel coronavirus from patients with pneumonia in China, 2019. N Engl J Med 382:727-733. https:// doi.org/10.1056/nejmoa2001017

Zou L, Ruan F, Huang M, Liang L, Huang H, Hong Z, Yu J, Kang M, Song Y, Xia J, Guo Q, Song T, He J, Yen H-L, Peiris M, Wu J (2020) SARS-CoV-2 viral load in upper respiratory specimens of infected patients. N Engl J Med 382:1177-1179. https://doi. org/10.1056/nejmc2001737

Zucker I, Lester Y, Alter J et al (2021) Pseudoviruses for the assessment of coronavirus disinfection by ozone. Environ Chem Lett. https://doi.org/10.1007/s10311-020-01160-0

Publisher's Note Springer Nature remains neutral with regard to jurisdictional claims in published maps and institutional affiliations. 